\title{
Pemberdayaan Ekonomi Masyarakat di Kampung Idiot Karangpatihan Balong Ponorogo
}

\author{
Hanafi Hadi Susanto \\ Institut Agama Islam Negeri Ponorogo, Indonesia \\ hanafihadi12@gmail.com
}

\begin{abstract}
Abstrak: Pemberdayaan ekonomi menjadi tren menarik yang diperbincangkan, khususnya pemberdayaan dengan sasaran masyarakat menyandang tunagrahita atau sering disebut idiot di wilayah 3T (Terpencil, Terluar dan Tertinggal). Pemberdayaan pada masyarakat yang tidak umum ini akan memiliki keunikan dan corak yang berbeda jika dibandingkan pemberdayaan pada masyarakat homogen dan masyarakat normal pada umumnya. Hal ini terbukti, program pemberdayaan di kampung idiot ini telah mendapatkan apresiasi baik tingkat wilayah maupun internasional. Penelitian ini termasuk penelitian kualitatif dalam kategori field research dengan sumber data utama kepala desa Karangpatihan, anggota keluarga tuna grahita, dan seluruh stakeholder desa Karangpatihan, selain itu data sekunder juga diperoleh dari arsip tertulis di kelurahan maupun hasil pantauan program pemberdayaan. Data yang telah terkumpul kemudian dikelompokkan sesuai rumusan masalah selanjutnya dilakukan analisis untuk memperoleh simpulan. Tulisan ini akan mengungkap bagaimana aksi pemberdayaan mulai dari strategi, metode dan keberhasilan pemberdayaan di kampung idiot Karangpatihan Balong Ponorogo. Tulisan ini bermaksud mengisi kelangkaan literatur yang memfokuskan kegiatan pemberdayaan masyarakat keterbelakangan mental, tidak memahami financial hingga mampu memberikan nafkah untuk anggota keluarga. Untuk itu, rumusan masalah mencakup bagaimana ekonomi masyarakat, langkah-langkah pemberdayaan ekonomi, tingkat keberhasilan pemberdayaan dan faktor pendukung, penghambat dan solusi dalam pelaksanaan pemberdayaan di kampung idiot Balong, tulisan ini menemukan bahwa ada tiga klasifikasi penyandang tunagrahita Karangpatihan Balong Ponorogo, yaitu kategori ringan sebanyak 46 orang (48\%). 46 orang terdiri dari 26 laki-laki dan 20 perempuan, kategori sedang sebanyak 38 orang (42\%). Dari hasil penelitian, ditemukan inovasi-inovasi strategi pemberdayaan ekonomi pada masyarakat tunagrahita secara rinci disetiap tahapan, bahkan kendala dan solusi mampu diungkap dan ini dapat dijadikan pedoman pada program pembberdayaan di tempat lain.
\end{abstract}

Kata Kunci: Pemberdayaan ekonomi, tunagrahita, kampung idiot.

Abstract: Economic empowerment has become an interesting trend to be discussed, especially empowerment with the target of people with mental retardation in remote, outermost and disadvantaged areas. Empowerment in this unusual society will have a unique and different style when compared to empowerment in a homogeneous society and normal society in general. This is evident, the empowerment program in this mentally retarded villages has received 
appreciation at both regional and international levels. The research includes qualitative research in the field research category with the main data sources being the Karangpatihan village head, mentally disabled family members, and all steak holders in Karangpatihan village, besides that secondary data is also obtained from written archives in the village and the results of monitoring empowerment programs. The data that has been collected is then according to the formulation of the problem, then an analysis is carried out to obtain conclusions. This paper wants to investigate how the empowerment action starts from the strategy, method and success of empowerment in the mentally retarded villages Karangpatihan Balong Ponorogo. This paper intends to fill in the scarcity of literature that focuses on empowering people with mental retardation, not understanding finances to being able to provide a living for family members. To that end, the formulation of the problem includes how the community's economy is, measures for economic empowerment, the success rate of empowerment and supporting factors, obstacles and solutions in implementing empowerment in the Balong mentally retarded villages. That is the light category as many as 46 people ( $48 \%)$. 46 people consisting of 26 men and 20 women, the medium category was 38 people $(42 \%)$. From the results of the study, it was found that innovations in economic empowerment strategies for mentally retarded communities were in detail at each stage, even obstacles and solutions could be revealed and these could be used as guidelines for empowerment programs elsewhere.

Keywords : Economic empowerment, mentally retarded, mentally retarded village

\section{PENDAHULUAN}

Idiot "Tunagrahita" adalah istilah yang digunakan untuk menyebut anak yang mempunyai kemampuan intelektual di bawah rata-rata (Somantri, 2006). Disamping itu mereka mengalami keterbelakangan dalam menyesuaikan diri dengan lingkungan. Mereka kurang cakap dalam memikirkan hal-hal yang abstrak, yang sulit-sulit, dan yang berbelit-belit (Moh.Amin). Desa Karangpatihan merupakan salah satu wajah potret buram kemiskinan, meski hanya berjarak $23 \mathrm{~km}$ dari Ponorogo. Posisi desa diapit oleh empat gunung kapur yang gersang. Sebelah selatan berdiri Gunung Prongos, di barat ada Gunung Lumbung dan Rajegwesi, serta sebelah utara Gunung Bangkong (Statistik, 2016). Kondisi gersang dan susah air irigasi membuat tanah desa tak subur. Hanya ketela dan sejenisnya yang bisa tumbuh. Bila musim kemarau, yang terlihat di kanan-kiri adalah bebukitan yang panas meranggas. Kondisi alam yang tandus membuat warganya kekurangan gizi. Bahkan, terdapat puluhan penderita tunagrahita. 
Munculnya sebutan Kampung Idiot pertama kali pada tahun 2008, dari pemberitaan melalui berbagai media cetak maupun elektronik yang salah satu wartawan juga mahasiswa yang waktu itu diajak untuk meliput aktivitas masyarakat tunagrahita. Sebutan itu tidak hanya dikenal oleh masyarakat sekitar desa saja, melainkan sampai masyarakat luas. Hal ini memang tidak bisa di pungkiri lagi, karena jika kabar tersebut masuk dalam media cetak maupun elektronik maka kalangan masyarakat yang jauh dari Desa Karangptihanpun dapat mengetahuinya (2013). Dengan sebutan Kampung "Idiot" Desa Karangpatihan maka pemerintah desa maupun daerah harus berupaya untuk menghilangkan sebutan tersebut dengan cara memberikan pemberdayaan terutama untuk meningkatkan kualitas gizi dan juga pendidikan untuk masyarakat dengan keterbelakangan mental, supaya dikemudian hari tidak ada kelahiran anak atau masyarakat dengan menderita keterbelakangan mental.

Desa Karangpatihan berdiri di tanah tandus kering kawasan lereng gunung kapur. Dengan situasi alam seperti ini jelas warga dusun tersebut tidak mungkin dapat menggerakan ekonomi mereka dengan cara bertani atau berkebun. Tidak tersediannya koperasi simpan pinjam dan pasar untuk menggerakan ekonomi masyarakat juga memperburuk situasi di dusun ini. Alhasil banyak warga dusun ini masuk kedalam lubang kemiskinan yang lebih dalam dibanding didaerah lain di Kabupaten Ponorogo. Tercatat 290 Kepala Keluarga (KK) di dusun ini hidup dibawah Garis Kemiskinan kabupaten Ponorogo dan $561 \mathrm{KK}$ hidup hampir miskin (Dwilaksono, 2016). Parahnya lagi akibat tekanan ekonomi dan mahalnya bahanbahan pokok di dusun ini, banyak dari warga di dusun ini menjadikan nasi Gaplek atau tiwul sebagai makanan utamanya selama bertahun-tahun, alhasil, banyak dari warga mengalami masalah gizi buruk yang konon menjadi penyebab retardasi mental yang turun temurun di dusun ini. Dari jumlah populasinya, penyandang Tunagrahita di dusun ini memang terus meningkat. Saat ini terdapat 48 KK dengan total 98 orang menyandang Tunagrahita. Jumlah ini mengalami peningkatan dari 69 orang di tahun 2011 (Date Desa Karangpatihan, 2011)

Seperti layaknya komunitas Tunagrahita lainnya, warga Tunagrahita di dusun ini juga mempunyai berbagai tantangan dan hambatan untuk menjadi insan yang 
mandiri layaknya orang pada umumnya. Sebagai contoh, warga Tunagrahita di dusun ini tidak dapat mendapat pekerjaan karena keterbatasan fisik, kemampuan kognitif dan rasa minder yang dimilikinya meskipun sesungguhnya mereka masih relatif muda atau dalam masa-masa usia produktif. Alhasil warga Tunagrahita ini terus dilihat sebagai beban keluarga dan lingkungan dusun ini. Ada beberapa bidang yang perlu di bangun pada masyarakat desa Karangpatihan tersebut khususnya penderita tunagrahita. Pembangunan desa dari seorang pioner; kepala desa Karangpatihan meliputi pembangunan dibidang ekonomi,sosial, budaya, pariwisata dan juga agama.

Layaknya agama, ekonomi mempunyai peran yang dominan agar hidup tetap stabil dan terarah pada jalan yang benar. Ekonomi menjadi salah satu indikator dalam upaya mewujudkan suatu kehidupan yang bermakna, damai dan bermanfaat. Menyadari betapa pentingnya ekonomi bagi kehidupan umat manusia, maka penanaman (internalisasi) nilai-nilai ekonomi dalam kehidupan setiap pribadi tuna grahita menjadi sebuah keharusan atau kewajiban, yang ditempuh melalui pelatihan maupun pendidikan non formal (Munardji, 2004).

Penyandang tunagrahita perlu mendapat perhataian khusus dalam masalah ekonomi agar mereka tetap menjadi tangguh dalam menghadapi tantangan, hambatan dan perubahan yang muncul dalam pergaulan di dalam masyarakat. Pemberdayaan ekonomi pada masyarakat diwilayah 3T (terpencil, terluar dan tertinggal) sangat berbeda dengan masyarakat homogen, apalagi masyarakat mempunyai keterbelakangan mental (idiot). Strategi, inovasi dan hambatan sangat mempengaruhi keberhasilan program pemberdayaan di Karangpatihan Balong Ponorogo.

Pentingnya isu pemberdayaan pada masyarakat $3 \mathrm{~T}$ khususnya masyarakat tuna grahita, belum gayung bersambut dengan literatur yang tersedia. Umumnya literatur filantropi untuk pemberdayan masih fokus dalam masyarakat homogen. Di antara literatur tersebut adalah artikel Besse Wediawati (Wediawati, 2012) "Revitalisasi Filantropi Islam di Kota Jambi", artikel Aan Nasrullah (2015) yang berjudul "Pengelolaan Dana Filantropi untuk Pemberdayaan Pendidikan Anak Dhuafa: Studi Kasus pada BMH Cabang Malang Jawa Timur”, artikel Amril 
Maryolo "Filantropi Berbasis Faith Based Organization di Indonesia: Studi Kasus Program PKPU” (Maryolo, 2018).

Tulisan ini bermaksud mengisi kekosongan literatur tentang pemberdayaan pada masyarakat berkebutuhan khusus (idiot) di wilayah 3T. Untuk itu, rumusan masalah dapat dijabarkan menjadi: bagaimana ekonomi masyarakat, langkahlangkah pemberdayaan ekonomi, tingkat keberhasilan pemberdayaan dan faktor pendukung, penghambat dan solusi dalam pelaksanaan pemberdayaan di kampung idiot Balong Penelitian tunagrahita di Balong Ponorogo sudah beberapa kali dilakukan, tetapi karya yang sudah terbit tidak membahas secara mendalam strategi di masing-masing tahapan, tidak menganalisa faktor yang dihadapi dalam program pemberdayaan dan lebih mengupdate perkembangan di lapangan. Penelitian ini hamper sama dengan penelitian Lutfi Anatashia, tetapi penelitian Lutfi cenderung mengungkap apakah tunagrahita mampu hidup ditengah masyarakat normal pada umumnya, sementara penelitian ini fokus pada latar belakang ekonomi masyarakat, strategi, keberhasilan pemberdayaan, faktor pendukung dan penghambat pemberdayaan ekonomi di kampung idiot Balong Ponorogo.

\section{TINJAUAN LITERATUR}

\section{Konsep Pemberdayaan Ekonomi}

Pemberdayaan ekonomi adalah serangkaian kegiatan untuk memperkuat dan atau mengoptimalkan keberdayaan (dalam arti kemampuan dan atau keunggulan bersaing) kelompok lemah dalam masyarakat, termasuk individu-individu yang mengalami masalah kemiskinan. Sebagai proses, pemberdayaan merujuk pada kemampuan, untuk berpartisipasi memperoleh kesempatan dan atau mengakses sumberdaya dan layanan yang diperlukan untuk memperbaiki mutu hidupnya (baik secara individual, kelompok, dan masyarakatnya dalam arti luas). Dengan pemahaman seperti itu, pemberdayaan dapat diartikan sebagai proses terencana untuk meningkatkan skala/upgrade utilitas dari obyek yang diberdayakan. Pemberdayaan masyarakat adalah suatu proses dimana masyarakat, terutama mereka yang miskin sumber daya, kaum perempuan dan kelompok yang terabaikan 
lainnya, didukung agar mampu meningkatkan kesejahteraannya secara mandiri (Totok M, 2012).

Winarni mengungkapkan bahwa inti dari pemberdayaan adalah meliputi tiga hal yaitu pengembangan, (enabling), memperkuat potensi atau daya (empowering), terciptanya kemandirian (Winarni, 1998). Logika ini didasarkan pada asumsi bahwa tidak ada masyarakat yang sama sekali tanpa memiliki daya. Setiap masyarakat pasti memiliki daya, tetapi kadang-kadang mereka tidak menyadari atau daya tersebut masih belum diketahui secara eksplisit. Oleh karena itu daya harus digali dan dikembangkan. Jika asumsi ini berkembang maka pemberdayaan adalah upaya untuk membangun daya, dengan cara mendorong, memotivasi dan membangkitkan kesadaran akan potensi yang dimiliki serta berupaya untuk mengembangkannya. Di samping itu hendaknya pemberdayaan jangan menjebak masyarakat dalam perangkap ketergantungan (charity), pemberdayaan sebaliknya harus mengantarkan pada proses kemandirian (Tri Winarni 1998, 76).

Selain inti pemberdayaan menciptakan kemandirin ekonomi, terdapat tujuan yang lebih utama dalam perberdayaan ekonomi yaitu menguatkan akidah dan keimanan. Kondisi ekonomi yang lemah (walaupun tidak selalu) sangatlah dekat dengan instabilitas mental-iman seseorang. Sebagaimana dalam Hadits disebutkan: hampir kekafiran dekat dengan kekufuran. Dari hadis di atass sangat jelas bahwa lemah/tidak berdayanya ekonomi masyarakat akan mengancam keimanan. Ketika iman hilang, seseorang hidup dan berbuat sesuka hatinya dan pada akhirnya banyak menimbulkan kerusakan.

\section{Tunagrahita}

Tunagrahita merupakan gangguan atau hambatan yang dialami seseorang dalam perkembangan daya fikir maupun kepribadian, sehingga tidak mampu hidup sendiri dalam masyarakat (membutuhkan pendampingan) (Munzayanah, 2000). Pendapat lain mengatakan, tunagrahita adalah seseorang yang memiliki kecerdasan dibawah rata-rata orang pada umurnya dan mengalami hambatan penyesuaian diri dengan lingkungannya (Apriyanto, 2012).

Pengelompokan tunagrahita menurut Novan Ardy Wiyani adalah tunagrahita ringan, tunagrahita sedang, tunagrahita parah. Tunagrahita ringan adalah yang 
mampu didik meskipun hasilnya tidak maksimal. Orang tersebut dapat didik dalam bidang akademiknya seperti membaca, menulis, mengeja, dan berhitung, dapat menyusaikan diri dan tidak bergantung pada orang lain, dapat memiliki keterampilan sederhana untuk kepentingan kerja dikemudian hari. Tuna grahita sedang adalah anak yang memiliki kisaran IQ 54-40. Mereka memiliki kisaran IQ dibawah tunagrahita ringan sehingga tidak mungkin mampu mengikuti program yang diperuntukkan bagi anak tunagrahita ringan. Beberapa kemampuan yang perlu diajarkan pada anak tunagrahita sedang yaitu anak belajar mengurus diri sendiri, misalnya makan, memakai pakaian, mandi, tidur, dan lainya. Anak juga dapat diajarkan dengan penyesuaian diri di lingkungan rumah dan sekitarnya. Juga dapat mempelajari kegunaan ekonomi dirumah atau di lembaga khusus (Wiyani, 2014). Tuna grahita parah adalah yang memiliki kisaran IQ 24-0. Mereka memiliki IQ yang sangat rendah sehingga ia tidak mampu mengurus dirinya sendiri atau bersosialisasi. Mereka membutuhkan orang lain untuk mengurus dirinya. Jadi tuna grahita parah ini memerlukan perawatan sepenuhnya sepanjang hidupnya.

\section{Kendala Pemberdayaan Ekonomi}

Kendala-kendala atau kesulitan yang dihadapi dalam pemberdayaan ekonomi masyarakat pada masyarakat tunagrahita "idiot" dibagi menjadi dua, yaitu kendala internal dan eksternal.

a. Kendala internal

Kendala internal adalah kendala yang dialami oleh lembaga maupun masyarakat yang diberdayakan, antara lain: terbatasnya kemampuan sumber daya manusia, keterbatasan kemampuan manajerial, tidak adanya kemampuan mengelola peluang pasar yang ada dan terbatasnya modal usaha yang dimiliki.

b. Kendala eksternal

Kendala eksternal adalah kendala yang disebabkan diluar kendala internal (bukan dari lembaga maupun masyarakat), antara lain: akses menuju lokasi yang sangat jauh dari perkotaan, belum adanya pihak swasta lain yang benarbenar fokus mengelola bantuan modal usaha sebagai partisipasi dalam pemberdayaan ekonomi masyarakat (Arsiyah, 2009).

Tahapan Pemberdayaan untuk Kemandirian Sosio-Ekonomi Masyarakat 
Implikasi pemberdayaan dapat dilihat dari banyak aspek, salah satunya adalah dengan melihat perubahan sosio-ekonomi masyarakat. Perubahan sosial menurut pendapat Selo Soemardjanadalah segala perubahan pada lembaga-lembaga kemasyarakatan dalam suatu masyarakat yang mempengaruhi sistem sosialnya, termasuk di dalamnya nilai-nilai, sikap dan pola perilaku di antara kelompokkelompok dalam masyarakat (Soemardjan, 1982). Sumodiningrat menjelaskan bahwa keberdayaan masyarakat yang ditandai adanya kemandiriannya dapat dicapai melalui proses pemberdayaan masyarakat (Winarni, 1998). Keberdayaan masyarakat dapat diwujudkan melalui partisipasi aktif masyarakat yang difasilitasi dengan adanya pelaku pemberdayaan (Sumodiningrat, 2000). Menurut Suparjan \& Hempri S memberdayakan masyarakat dibutuhkan tahapan-tahapan yang jelas dan terarah untuk mencapai sebuah kemandirian ekonomi (Suparjan, 2003).

Perubahan sosial meliputi perubahan dalam berbagai hal, seperti perubahan teknologi, perilaku, norma, sistem nilai, pola dan keyakinan. Kemandirian masyarakat adalah suatu kondisi yang dialami masyarakat yang ditandai oleh kemampuan untuk memikirkan, memutuskan serta melakukan sesuatu yang dipandang tepat demi mencapai pemecahan masalah-masalah yang dihadapi (Sabarisman, 2017) dengan memperuntukkan daya dan kemampuan yang terdiri atas kemampuan kognitif, konatif, psikomotorik, dengan pengerahan sumber daya yang dimiliki oleh lingkungan internal masyarakat tersebut, dengan demikian untuk menuju mandiri perlu dukungan kemampuan berupa sumber daya manusia yang utuh dengan kondisi kognitif, konatif, psikomotorik dan afektif, dan sumber daya lainnya yang bersifat fisik -material (Ambar, 2004).

Dalam memberdayakan masyarakat dibutuhkan tahap pemberdayaan yang jelas dan terarah, disebutkan tahap-tahap pemberdayaan menurut Suparjan \& Hempri S dalam rangka pemberdayaan masyarakat ada beberapa hal yang harus dilakukan antara lain (Suyatno, 2003):

a. Meningkatkan kesadaran kritis atau posisi masyarakat dalam struktur sosial politik. Hal ini berangkat dari asumsi bahwa sumber kemiskinan berasal dari konstruksi sosial yang ada pada masyarakat itu sendiri. 
b. Kesadaran kritis yang muncul diharapkan membuat masyarakat mampu membuat argumentasi terhadap berbagai macam eksploitasi serta sekaligus membuat pemutusan terhadap hal tersebut.

c. Peningkatan kapasitas masyarakat. Dalam konteks ini perlu dipahami, bahwa masalah kemiskinan bukan sekedar persoalan kesejahetraan sosial tetapi berkaitan dengan faktor politik, ekonomi sosial budaya dan keamanan.

d. Pemberdayaan juga perlu meningkatkan dengan pembangunan sosial budaya masyarakat

\section{METODE PENELITIAN}

Pembahasan pemberdayaan pada masyarakat tunagrahita (idiot), menjadi objek yang begitu menarik dalam sebuah praktik pemberdayaan. Selain metode yang diterapkan penuh dengan inovasi dan inspirasi, melakukan interaksi maupun komunikasi dalam optimalisasi progran menjadi tantangan bagi penggerak pemberdayaan di kampung Idiot Karangpatihan Balong. Penelitian terhadap topik ini memilih jenis penelitian kualitatif dalam kategori field research dengan sumber data utama kepala desa Karangpatihan sebagai penggagas program dan penanggung jawab, anggota keluarga tuna grahita, dan seluruh steak holder desa Karangpatihan. Sumber data lain berupa peristiwa, benda, gambar, rekaman dan dokumen yang ada di kampong idiot Karangpatihan, baik yang sudah dan sedang berlangsung. Data yang diperoleh dari masing-masing sumber dicocokan dengan data maupun sumber-sumber lainnya, sehingga data yang diperoleh benar-benar valid. Teknik analisa data mengacu pada model interaktif Miles and Huberman yang meliputi: koleksi data, reduksi data, display data, dan verifikasi. Semua tahapan analisis mengacu sepenuhnya pada rumusan masalah yang telah ditetapkan. Setelah data yang diperoleh dari sumber-sumber data terkumpul, data dikelompokkan sesuai fokus rumusan, dan melakukan pendialogan antara data dan teori pemberdayaan. Adanya pendialogkan dan pembahasan yang mengerucut diperoleh sebuah simpulan penelitian.

\section{HASIL DAN PEMBAHASAN}




\section{Pemberdayaan Ekonomi Masyarakat di Kampung Ideot}

Karangpatihan Balong yang dijuluki sebagai kampong idiot menjadi satu tantangan bagi kepala desanya untuk membangun perekonomian warganya. Keterbelakangan mental menjadikan hal yang sangat sulit dalam mewujudkan desa/kampung yang ekonominya berdaya. Strategi dan metode pemberdayaan ekonomi di daerah semacam ini berbeda jauh dengan pemberdayaan ekonomi pada masyarakat normal, berpendidikan, dan mudah dalam komunikasi.

\section{Kondisi mental masyarakat kampung "idiot" Karangpatihan}

Ada tiga klasifikasi penyandang tunagrahita (Moh. Amin, 1995) di Karangpatihan Balong Ponorogo, yaitu kategori ringan, kategori sedang dan kategori berat. Klasifikasi ini sesuai dengan ciri-ciri masing-masing orang dan menurut pihak pendamping desa sendiri, bukan secara medis. Berdasarkan wawancara atau keterangan dari warga atau anggota keluarganya, deskripsi masingmasing klasifikasi adalah sebagai berikut:

Kategori ringan, ini merupakan kategori tunagrahita yang bisa diartikan mereka tidak terlalu banyak melakukan tindakan yang merugikan dan pengawasan yang ketat serta bersifat terus menerus (Mumpuniarti, 2007). Mereka lebih menurut untuk diatur serta dicegah apabila bertindak sesuatu yang tidak diinginkan baik oleh pihak keluarga itu sendiri maupun lingkungan sosial masyarakat sekitarnya.

Kaum tunagrahita dalam keluarga tersebut terkadang bicara sendiri, marah namun mudah dinasehati dan mudah sembuh atau sadar, dinasehati terkadang nyambung, kadang tidak nyambung, keluar sampai larut malam, tidak jelas cara bicaranya, lupa tidak menjaga kebersihan, Kondisi malas bekerja juga tidak bekerja terlebih kondisi tidak ada keinginan seringkali pilih diam diri, Masalah ketidakrapian kerja merupakan hal biasa namun paling tidak bisa bantu membantu (Mulyadi, 2021).

Aktivitas mereka diantaranya merawat jagung seperti bedul suket, matun, merawat sapi, dibiasakan membantu masak, bagi yang biasa merumput juga merumput namun kadang lupa peralatan tidak dibawa pulang dan hilang, kadang tidak mau merumput apabila kondisi marah dan hanya diam, melamun sendiri, 
namun terkadang langsung sembuh atau sadar dengan sendirinya dan kembali melakukan aktivitas yang memang sudah menjadi pekerjaannya. Selain itu bagi yang terbiasa masak kadang yang penting matang kadang segar, kadang rasa tidak jelas namun sudah biasa namun kategori ringan pada dasarnya mudah dikendalikan.

Pada intinya dari beberapa penjelasan tersebut dapat digambarkan bahwa bentuk tindakan, perilaku pada warga penyandang tunagrahita kategori ringan di Kampung "idiot" Dusun Tanggungrejo terkait pada kelupaan, kelalaian dan ketidakrapian, melamun, ngomong sendiri, marah, namun cenderung mudah dikendalikan dalam artian mudah dinasehati, mudah diatur, mudah untuk ditata serta amarah atau jengkelnya mudah hilang karena diantaranya masih bisa mengerti komunikasi tentang arahan-arahan baik dalam praktik pelatihan pada saat mengikuti kegiatan maupun pada praktik secara langsung, baik dalam bidang pertanian maupun peternakan dalam kesehariannya di lingkungan keluarga maupun lingkungan masyarakat terkait. Selain dengan komunikasi yang mudah dipahami juga dengan materi baik berupa pakaian, makanan maupun barangbarang lain yang disukai. Di Dusun Tanggungrejo Karangpatihan Balong yang masuk dalam kategori tunagrahita ringan sebanyak 46 orang (48\%). 46 orang terdiri dari 26 laki-laki dan 20 perempuan (Tunagrahita, 2015). Tunagrahita sedang, Terkait sikap, perilaku serta tindakan warga tunagrahita kategori sedang pada Kampung "idiot" Dusun Tanggungrejo memiliki keberadaan yang berbeda yaitu lebih sulit dikendalikan dibandingkan dengan tunagrahita kategori ringan hal ini terkait dengan perilaku serta tindakan yang dimiliki baik tidak merugikan maupun dianggap merugikan oleh keluarga maupun masyarakat sekitar.

Berdasarkan beberapa penjelasan warga Kampung "idiot" Dusun Tanggungrejo, terkait perilaku dan tindakan yang dimiliki oleh penyandang tunagrahita kategori sedang baik yang dianggap merugikan maupun yang dianggap merugikan bagi keluarga dan masyarakat lingkungan sekitar. Sebagian besar cenderung berfariasi serta lebih parah dibandingkan dengan tunagrahita kategori ringan (Mulyadi, Wawancara, 2020). Diantaranya sebagian besar sering mengamuk dengan sendirinya, sering ngomong sendiri, terkadang lupa dengan apa yang 
harus dilakukan dan yang diperintahkan, sering melamun, belum tentu mau untuk bekerja serta berkerajinan meskipun pekerjaan itu memang pekerjaan dirinya, serta komunikasi yang tidak jelas pula terlebih pada penyandang bisu sekaligus. Di desa Karangpatihan Balong Ponorogo yang masuk dalam kategori tunagrahita sedang sebanyak 38 orang (42\%). Jumlah tunagrahita sedang ini terdiri dari 24 lakilaki dan 14 perempuan. Tunagrahita sedang mayoritas diderita oleh kaum laki-laki.

Tunagrahita berat, Kategori ini bisa diartikan kategori yang banyak memerlukan pengawasan serta pengendalian dan pengasuhan (Mumpuniarti. 2007) baik dari keluarga itu sendiri maupun masyarakat sekitar di Kampung "idiot" Dusun Tanggungrejo. Sebagian besar kategori berat disandang pada warga tunagrahita serta penyandang bisu sekaligus. Dimana perilaku dan tindakan warga tersebut merupakan aktifitas yang ekstrim dalam kesehariannya. Berdasarkan hasil wawancara, dapat disarikan bahwa tunagrahita kategori berat merupakan warga penyandang yang memerlukan pengawasan, penjagaan, pengasuhan serta pendampingan secara terus menerus baik dari anggota keluarga terkait maupun dari warga masyarakat sekitar di Kampung "idiot" Dusun Tanggungrejo. Diantara pengendali tersebut karena mereka berkecenderungan memiliki aktifitas yang dipandang dapat merugikan baik bagi keluarga itu sendiri maupun masyarakat sekitar seperti mengamuk, merusak barang, menangis berlebihan, mengganggu tetangga. Dalam kesehariannya hanyalah makan, main dan tidak bisa bekerja sama sekali. Selain itu sebagian besar menyandang tunagrahita kategori berat juga penyandang tunagrahita bisu sekaligus sehingga tidak bisa berkomunikasi hanyalah diam diri dan atau menangis.

Jumlah tunagrahita desa Karangpatihan yang termasuk kategori tunagrahita ini sebanyak 5 orang (10\%). Kategori tunagrahita berat di desa Karangpatihan terdiri 3 orang laki-laki dan 2 orang perempuan. Dapat dikatakan orang laki-laki penyandang tunagrahita kategori berat lebih banyak dibanding kaum perempuan (Mulyadi, Wawancara, 2020). Berdasarkan jumlah data tunagrahita yang ada di desa Karangpatihan Kecamatan Balong adalah 89 orang, namun sebenarnya berdasarkan pendapat (wawancara) dengan Bapak lurah Karangpatihan jumlah 
yang sebenarnya berjumlah 98 orang. Jumlah tunagrahita yang tidak masuk dalam data desa 9 orang. Jumlah ini menurut kepala desa Karangpatihan sengaja disembunyikan dengan alasan tidak adanya ijin dari pihak keluarga yang bersangkutan untuk di data atau di ekspos.

\section{Kondisi ekonomi masyarakat kampung “idiot” Karangpatihan}

Dalam melakukan program pemberdayaan yang optimal sesuai sasaran langkah paling utama adalah sasaran lokasi pemberdayaan. Hal ini berkaitan dengan tujuan sebuah pemberdayaan, yaitu menjadikan masyarakat yang ekonominya lemah menjadi berdaya (Totok M 2012, 62). Dusun Tanggungrejo Karangpatihan atau dikenal sebagai kampung "idiot" merupakan kampung yang tergolong miskin dimana banyak penduduk yang terlilit kemiskinan. Kondisi tanahnya yang tandus berwarna cokelat, mudah kering sehingga masyarakat sangat ketergantungan dengan air terutama pada sektor pertanian dan peternakan. Pada saat musim penghujan mereka bisa bercocok tanam, itu pun hanya bisa menanam dua kali tanaman pokok dalam setahun bahkan hanya sekali, diantaranya silir berganti antara jagung, kacang tanah dan padi sedangkan ketela merupakan tanaman tahunan yang ditanam secara tumpangsari pada musim hujan dengan tanaman-tanaman lain.

Menurut Oksana, fungsi hutan yang semakin berkurang akibat pergantian pohon, pembukaan pemanfaatan lahan untuk pertanian, penebangan pohon untuk dijadikan arang, repek atau pencari suluh (Oksana, 2012). Sehingga berakibat pada terlambatnya sungai mengalir seperti yang terjadi biasanya bulan Desember sudah mulai mengalir dan ternyata sering masih kering, begitu musim kemarau tiba air sungai lebih dulu kekeringan. Kondisi sungai yang semakin kurang baik akibat banyak sumber air yang mati, banyak warga bertani dengan membuat sumur di tengah-tengah ladangnya secara besar-besaran, hal tersebut semakin menambah kesulitan sumber mata air untuk mengeluarkan air. Keadaan ini menjadi salah satu pemicu terjadinya kemiskinan/ketidak makmuran masyarakat.

Faktor lain yang menyebabkan lemahnya ekonomi di kampung "ideot" Dusun Tanggungrejo yaitu terbatasnya jumlah tenaga kerja normal dalam satu 
keluarga, ditambah dengan adanya kelemahan fisik beberapa warga pelaku strategi kelangsungan hidup akibat lanjut usia yang telah ditinggal suami atau istrinya dan memiliki anak penyandang tunagrahita yang tentunya membutuhkan sandang, papan dan pangan untuk bertahan hidup.

Dari segi pertanian di wilayah ini, pengolahan tanah belum begitu terkontrol dengan baik, sehingga penggarapan lahan tidak begitu memperhatikan kelangsungan jangka panjang. Salah satu contoh banyaknya penggundulan hutan sebagai tempat bertahan hidup hewan liar mengakibatkan hewan menyerang tanaman warga karena kekurangan makan. Selain itu seringnya bantuan konsumtif dari pemerintah maupun swasta, membuat warga pasif dalam produktifitas ekonomi mereka.

Kemajuan teknologi dan informasi menjadi penting adanya mengingat segala informasi banyak diketahui melalui media elektronik baik informasi ekonomi, sosial, politik, budaya, kesehatan, pendidikan dan sebagainya (Ardi, 2013). Namun media elektronik tidak semua kalangan masyarakat mampu mengakses. Begitu juga masyarakat Dusun Tanggungrejo sebagian kecil yang bisa mengakses media elektronik seperti televisi, hand phone dan lain sebagainya.

Bentuk kemiskinan struktrur terkait kebijakan yang dicanangkan oleh pemeritah tidak sesuai dengan sumber daya petani, peternak maupun buruh tani di Kampung “idiot” Dusun Tanggungrejo. Sehingga masyarakat teralienasi dari bentuk demokrasi Negara terkait kebijakan yang tidak sesuai dengan harapan masyarakat baik kebijakan yang berakibat pada peternakan, pertanian, pekerja maupun pertambangan. Alienasi terkait kemiskinan struktural ini secara tidak langsung Karl Marx dalam Magnis dan Suseno menunjukkan bahwa masyarakat melihat kerja dalam hal ini yaitu aktivitas masyarakat di bawah naungan demokrasi bukan sebuah ekspresi dari tujuan masyarakat.

Culture of poverty (budaya kemiskinan) yang terjadi di Kampung "idiot" Dusun Tanggungrejo merupakan kemiskinan yang disebabkan oleh adanya kekhawatiran akan pembentukan habitus baru, kepasifan, ketergantungan yang disebabkan oleh adanya utang piutang serta budaya solidaritas dan integrasi dalam bentuk kondangan berturut-turut sehingga membebani menyangkut pertumbuhan 
dan transformasi penduduk yang semakin meningkat berakibat pada terakumulasinya jumlah pernikahan maupun hajatan yang berturut-turut terutama di hari-hari besar.

Oscar Lewis dalam Mansour Fakih menyebutkan penyebab kemiskinan di Kampung "idiot" merupakan bentuk culture of poverty, yang dimaksudkan adalah adaptasi dan reaksi kaum miskin terhadap kedudukan marginal mereka dimana kebudayaan tersebut cenderung melanggengkan dirinya dari generasi ke generasi (Fakih, 2012).57). Kebudayaan tersebut mencerminkan upaya mengatasi keputusasaan dari harapan sukses di dalam kehidupan yang sesuai dengan nilai dan tujuan masyarakat yang lebih luas. Sehingga harus ada system pemberdayaan yang sesuai dengan keadaan dan kebutuhan masyarakat tunagrahita

\section{Pemberdayaan Ekonomi Masyarakat Kampung “Idiot” Karangpatihan}

Kondisi ekonomi yang lemah (walaupun tidak selalu) sangatlah dekat dengan instabilitas mental-iman seseorang. Sebagaimana dalam Hadits disebutkan:

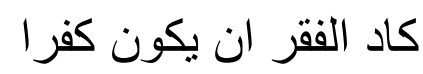

Artinya: Hampir kekafiran dekat dengan kekufuran.

Faktor kemiskinan di desa Karangpatihan kecamatan Balong Ponorogo, membuat mereka jauh dari mengenal agama. Oleh karena itu penguatan ekonomi masyarakat baik yang bersifat konsumtif seperti bantuan-bantuan tunai ataupun yang bersifat produktif seperti bantuan usaha permodalan, pembinaan ketrampilan kerja dan motifasi untuk mandiri secara ekonomi dipilih sebagai meteri pendampingan ekonomi. Bantuan program produktifitas yang telah dilakukan adalah :

a. Program harian berupa usaha pembuatan kerajinan keset. Program ini diperuntukkan masyarakat tunagrahita tingkat ringan dan sedang, dan tidak diperuntukkan bagi tunagrahita berat karena pembuatan keset sedikit rumit. Tunagrahita yang mengikuti program ini mampu mendapatkan penghasilan harian dengan jumlah berfariatif tergantung kekuatan masing-masing individu.

b. Program mingguan berupa pembuatan batik ciprat. Program ini rata-rata diikuti oleh tunagrahita ringan, yang mana pembuatan batik lebih rumit dibandingkan 
pembuatan keset. Pembuatan batik yang tidak bisa instan mampu menambah penghasilan masyarakat tunagrahita dalam jangka mingguan.

c. Program bulanan berupa peternakan ayam kampung. Program ini mayoritas diikuti oleh tunagrahita berat, karena peternakan ayam kampung tidak begitu membutuhkan pelatihan dan bisa didampingi pihak keluarga. Tunagrahita tingkat berat yang tidak tahu menahu uang/kebutuhan, dengan mengikuti program ini setiap bulan bisa memberikan tambahan penghasilan untuk keluarganya.

d. Program tiga bulanan berupa peternakan lele. Untuk menentukan klasifikasi terhadap usaha yang mereka pilih, maka disesuaikan berdasarkan kemampuan mereka oleh tokoh masyarakat yang telah diajak kerjasama oleh steak holder yang ada. Program pemberdayaan ekonomi dengan program budidaya ikan lele diberikan setiap Kepala Keluarga tunagrahita sejak tahun 2014. Program kerajinan keset dan ayam kampung dilakukan sejak tahun 2013, sedangkan batik ciprat dimulai sejak tahun 2016

Sedangkan pemberdayaan ekonomi ini diusahakan dari dana zakat para pegawai di lingkungan kantor kementerian agama kabupaten ponorogo. Karena jelas dalam al Quran surat al Taubah ayat 60 ditegaskan bahwa mereka adalah salah satu diantara delapan golongan yang berhak menerima zakat.

Tingkat keberhasilan penyuluh dalam pemberdayaan ekonomi masyarakat kampung "idiot" Karangpatihan Balong Ponorogo

Dalam pemberdayaan ekonomi ini bisa dikatakan berhasil dengan prosentase keberhasilan 80\% (Berdasarkan hasil prosentase jumlah yang memenuhi target binaan dengan kurang memenuhi target berdasarkan jumlah keseluruhan anggota binaan, selain itu perbandingan antara sebelum dan sesudanh adanya bantuan pemberdayaan ekonomi masyarakat desa Karangpatihan khususnya tuna grahita terlihat sangat jauh. Sebelum adanya bantuan dan program pemberdayaan ekonomi bagi masyarakat desa karangpatihan khususnya tunagrahita mereka hanya mengandalkan tulang punggung keluarga saja. namun, setelah adanya program pemberdayaan ekonomi yang dilakukan penyuluh dan bekerjasama dengan tokoh masyarakat setempat mereka dapat melakukan sebuah usaha yang berdasarkan 
kemampuan mereka. Sehingga setiap hari mereka dapat menghasilkan pundi-pundi rupiah, yang semakin hari bisa membuat roda perekonomian mereka semakin bertambah baik.). Terbukti dengan kemandirian ekonomi para tunagrahita dengan bantuan dari dana zakat pegawai kantor kementerian agama kabupaten Ponorogo dengan kita wujudkan berupa bibit lele yang di pelihara di kolam depan rumah mereka masing-masing sebesar $1 * 2$ meter, atas kerjasama dengan kepala desa dengan program ekonominya. Hal ini sesuai dengan gagasan Winarmi bahwa dalam pemberdayaan ekonomi harus tercipta sebuah kemandiriantri (Tri Winarni 1998). Dengan demikian paling tidak mereka bisa menghasilkan uang untuk kebutuhan mereka sendiri sehingga tidak berlebihan tergantung dan menjadi beban bagi keluarga mereka (Berdasarkan hasil pantauan dan laporan mereka (tunagrahita) yang mengikuti program ini sebelumnya pendapatnya 0 Rupiah namun hingga saat ini setiap kali panen ikan (3 bulan) mereka mendapatkan penghasilan 50 ribu/program.). Sedangkan yang 20 persen kami anggap belum berhasil karena atas usaha mereka memelihara ikan lele terkadang ada ruginya. Jumlah tunagrahita yang berhasil budi daya ikan lele berjumlah $39 \mathrm{KK}$. Jumlah ini terdiri dari $26 \mathrm{KK}$ tunagrahita ringan dan $13 \mathrm{KK}$ tunagrahita sedang.

Sedangkan bantuan pemberdayaan untuk ayam kampung, batik ciprat maupun pembuatan kerajinan keset berdasarkan hasil laporan dikatakan berhasil, dengan prosentase keberhasilan 70\%. Tidak jauh dari program budidaya ikan lele, pemberdayaan dengan program ini bekerjasama dengan tokoh masyarakat. Dari hasil karya (batik ciprat dan pembuatan keset) pemasaranya bibantu oleh tokoh masyarakat sedangkan masyarakat (tunagrahita) masih sebatas membuat selanjutnya disetor/pada koordinator bagian yang mengelola hasil kerajinannya. Pendapatan bersih perajin keset setiap bulan lebih dari 700 Ribu Rupiah. Setiap satu keset membutuhkan waktu 5 jam dalam pembuatan, sehari minimal dapat menghasilkan 2 keset sedangkan harga satu keset sebesar 15.000 (lima belas ribu rupiah). Sedangkan pembuat batik ciprat setiap bulannya dapat mengumpulkan uang rata-rata tidak kurang dari 300.000, tergantung seminggu menghasilkan berapa buah. Untuk peternak ayam kampung penjualannya setiap 3 bulan sekali/setiap mereka membutuhkan uang dengan pelaporan yang jelas. 
Meskipun keberhasilan itu tidak melonjak drastis, namun setiap program ini semakin hari semakin berkembang dan perekonomian mereka semakin hari semakin lebih baik. Perkembangan ini diperoleh melalui pemantauan pengelola perkembangan program dan dengan tercapainya tujuan masing-masing program keberhasilan yang stabil meskipun tidak langsung melonjak tinggi, titik utama tercapainya indikator kemandirian yaitu kekuatan sumberdaya internal dengan kata lain dari masyarakat untuk masyarakat. Masyarakat mampu mengelola sendiri tanpa selalu pendampingan dan mampu melakukan manajemen secara mandirri (Malau, 2015). Jumlah tunagrahita yang mengiuti program ayam kampung berjumlah 50 orang yang terdiri dari 26 orang tunagrahita ringan dan 24 orang tunagrahita sedang. Jumlah total yang berhasil dalam program ayam kampung berjumlah 35 orang. Jumlah tunagrahita yang mengikuti program pembuatan keset 56 orang, terdiri dari tunagrahita ringan 46 Orang dan tunagrahita sedang 10 orang. Tunagrahita yang berhasil dalam pembuatan keset berjumlah 46 orang, Begitu juga tunagrahita yang mengikuti program pembuatan batik ciprat berjumlah 13 orang, terdiri dari 8 orang tunagrahita ringan 5 orang tunagrahita sedang. sedangkan $70 \%$ yang berhasil 9 orang. Seperti yang dikemukakan di atas bahwa tingkat keberhasilan ini dapat diukur salah satunya dengan membandigkan target/tujuan pemberdayaan dan hasil capaian atau hasil program. Selain itu keberhasil dibandingkan hitam putih perubahan antara sebelum adanya program dan perubahan setelah adanya program dilakukan.

Faktor pendukung, penghambat dan solusi pemberdayaan ekonomi masyarakat kampung “idiot" Karangpatihan Balong Ponorogo

Dalam pemberdayaan ekonomi masyarakat desa Karangpatihan kecamatan Balong, banyak faktor yang mempengaruhi proses pelaksanaan program. Faktorfaktor tersebut dapat diklasifikasikan dalam dua hal, yaitu faktor pendukung dan penghambat :

1. Faktor pendukung dalam pemberdayaan ekonomi masyarakat 3T Kampung “idiot” Karangpatihan Balong Ponorogo (Mulyadi, Wawancara, 2021)

a. Kesadaran para anggota keluarga untuk selalu memantau perkembangan saudaranya yaitu para tunagrahita. 
b. Sikap sabar dan ketlatenan steak holder dalam menyampaikan materi.

c. Materi yang diberikan diselaraskan dengan metode yang disesuaikan dengan kebutuhan binaan.

d. Dukungan moril dan spirituil dari perangkat desa dan masyarakat sekitar pada pelaksanaan kegiatan.

2. Faktor penghambat dalam pemberdayaan ekonomi Masyarakat $3 \mathrm{~T}$ Kampung “idiot” Karangpatihan Balong Ponorogo

Hambatan dalam pemberdayaan ekonomi secara umum adalah kesulitan dalam pendistribusian hasil karya para tunagrahita, terutama keset. Setiap kali keset itu jadi mereka tidak mau tau, saat itu juga harus terima upah (Tunagrahita K., 2021).

Upaya penyelesaian hambatan dan kendala dalam pemberdayaan ekonomi di kampong 3T (Mulyadi, 2021):

1. Upaya untuk mengatasi hambatan pengelola program

Adapun upaya untuk mengatasi hambatan dalam mengoptimalkan program di kampung "idiot", pengelola sering belajar dan berbagi dengan aktifis lembaga filantrophy dan juga berkoordinasi dengan keluarga binaan maupun perangkatperangkat dan masyarakat setempat, memberikan perhatian yang lebih kepada para masyarakat tuna grahita agar mereka semakin akrab dan nyaman.

2. Upaya untuk mengatasi hambatan

Dilakukan pendekatan personal kepada sasaran binaan, dengan mengetahui karakteristik masing-masing agar lebih efektif dalam mendampingi mereka sehingga mereka bisa mengembangkan kreatifitasnya sesuai dengan kemampuan dan kondisi mereka. Selain itu, paya untuk mengatasi pemberdayaan ekonomi adalah bekerjasama dengan berbagai pihak terutama dinas instansi untuk mengambil keset dari hasil para tunagrahita kapan membutuhkannya.

\section{PENUTUP}

Penelitian ini mendapatkan temuan menarik bahwa terdapat tiga klasifikasi penyandang tunagrahita Karangpatihan Balong Ponorogo. Yaitu kategori ringan 
sebanyak 46 orang (48\%). 46 orang terdiri dari 26 laki-laki dan 20 perempuan, kategori sedang sebanyak 38 orang (42\%). Jumlah tunagrahita sedang ini terdiri dari 24 laki-laki dan 14 perempuan, dan kategori berat sebanyak 5 orang (10\%). Kategori-kategori ini adalah menurut pihak pendamping desa sendiri, bukan secara medis maupun teori yang lainnya.

Dusun Tanggungrejo Karangpatihan atau dikenal sebagai kampung "idiot" merupakan kampung yang tergolong miskin dimana banyak penduduk yang terlilit kemiskinan. Beberapa faktor kemiskinan mereka adalah karena faktor alam, faktor keterbatasan tenaga kerja yang normal, faktor pola pikir, faktor kebijakan pemerintah, dan juga faktor budaya.

Langkah pemberdayaan dan strategi yang dilakukan dalam pemberdayaan ekonomi di Kampong Idiot adalah: Identifikasi potensi wilayah, menentukan metode pemberdayaan, koordinasi dan bekerjasama dengan pihak-pihak terkait, pelaksanaan program dan melakukan pemantauan serta evaluasi. Tingkat keberhasilan penyuluh dalam pemberdayaan ekonomi pada masyarakat Kampung "idiot" bisa dikatakan berhasil, karena sesuai dengan pembahasan bahwa hasil semua program pendampingan melebihi $65 \%$ target yang diprogramkan. Beberapa solusi/cara menangani kendala pemberdayaan ekonomi masyarakat salah satunya sering belajar, berbagi dengan penyuluh-penyuluh lain, berkoordinasi dengan keluarga binaan dan juga perangkat-perangkat dan masyarakat setempat.

\section{REFERENSI}

Aan, Nasrullah. (2015). Pengelolaan Dana Filantropi Untuk Pemberdayaan Pendidikan Anak Dhuafa (Studi Kasus Pada Bmh Cabang Malang Jawa Timur), Hunafa: Jurnal Studia Islamika 12, No. 1: 1-18.

Amril, Maryolo. (2018). Filantropi Berbasis Faith Based Organization Di Indonesia (Studi Kasus Program PKPU), Palita: Journal of Social Religion Research 2, no. 1: 13-24.

Arsiyah. (2009). Pemberdayaan Masyarakat Dalam Pembangunan Ekonomi Desa

(Studi Kasus Pemberdayaan Masyarakat Industri Kecil Krupuk Ikan di Desa Kedungrejo, Kecamatan Jabon, Kabupaten Sidoarjo), jurnal Wacana Vol. 12 
JoIE: Journal of Islamic Economics | Hanafi Hadi Susanto

No. Sidoarjo:375.

Badan Pusat Statistik Kabupaten Ponorogo. Balong Dalam Angka 2016.

Bagus, Kusuma Ardi. (2013). Pengaruh Kemajuan Teknologi Informasi Terhadap

Perkembangan Sistem Informasi Akuntansi, Jurnal Dharma Ekonomi No. 38/

Th. XX/ (STIE Dharmaputra Semarang, Oktober, 2.

Database tunagrahita desa Karangpatihan Balong Ponorogo tahun 2015.

Besse, Wediawati. (2012) . Revitalisasi Filantropi Islam Di Kota Jambi (Studi Pada Lembaga Zakat Dan Masyarakat Muslim Pemberi Derma Di Kota Jambi),” Jurnal Penelitian Universitas Jambi: Seri Humaniora 14, No. 1.

Database kelurahan Desa Karangpatihan Kecamatan Balong Kabupaten Ponorogo pada angka/tahun 2011.

Dwilaksono, Bangun..Statistik Daerah Balong 2016. Ponorogo: Badan Pusat Statistik Kabupaten Ponorogo. 2018.

Sumodiningrat, Gunawan. (2000). Visi dan Misi Pembangunan Pertanian Berbasis Pemberdayaan Yogjakarta: IDEA,

Suparjan, Hempri Suyatna. (2003), Pengembangan masyarakat dari pembangunan sampai pemberdayaan. Yogjakarta: Adityia Media.

Franz, Magnis Suseno. (2007). Memahami Hubungan Antar Agama. Yogyakarta: Elsaq Prees,

Fakih, Mansour. (2012). Analisis Gender \& Transformasi Sosial, Yogyakarta: Pustaka Pelajar.

Amin, Moh. (1995). Orthopedagogik Tunagrahita. Jakarta: Depdikbud

Mumpuniarti. (2007). Pembelajaran Akademik Bagi Tunagrahita. Yogyakarta: FIP UNY.

Munardji. (2004). Ilmu Pendidikan Islam, Jakarta: PT Bina Ilmu.

Munzayanah. (2000). Pendidikan Anak Tunagrahita. Surakarta: PLB-FKIP UNS.

Muslim, Sabarisman. (2011). Perubahan Sosial Dalam Pemberdayaan Masyarakat Miskin Perkotaan 'Pemberdayaan Melalui KUBE di Kelurahan Sayangsayang Kota Mataram, Sosio Konsepsia 17, no. 3 (2017): 252-268; Yofi Syahputra, "Dampak Sosial Ekonomi Masyarakat Atas Keberadaan PT. RAPP Estate Baserah Di Kecamatan Kuantan Hilir Kabupaten Kuantan Singingi” (PhD 
JoIE: Journal of Islamic Economics | Hanafi Hadi Susanto

Thesis, Universitas Islam Negeri Sultan Syarif Kasim Riau, 2016).Cholisin, "Pemberdayaan Masyarakat" (Gladi Manajemen Pemerintahan Desa Bagi Kepala Bagian/Kepala Urusan Hasil Pengisian Di Lingkungan Kabupaten Sleman, Kabupaten Sleman, 19-20 Desember 11).

Natalia, Artha Malau. (2015). Strategi Pemberdayaan Ekonomi Kerakyatan” Jurnal Ilmiah "Integritas" Vol.1 No. 4 Deseber, 5.

Wiyani, Novan Ardy. (2014). Buku Ajar Penanganan Anak Usia Dini. Yogyakarta: Ar-ruzz Media.

Apriyanto, Nunung. (2012). Seluk-Beluk Tunagrahita \& Strategi Pembelajarannya. Yogjakarta: JAVALITERA.

Oksana, (2012). Pengaruh Alih Fungsi Lahan Hutan Menjadi Perkebunan Kelapa Sawit Terhadapsifat Kimia Tanah, Jurnal Agroteknologi, Vol. 3 No. 1, .., Agustus, 31 .

Soemardjan, Selo. (1982). Perubahan Sosial di Yogyakarta. Yogjakarta: Gajah Mada University Press.

Suyatno, Suparjan dan Hempri. (2003). Pengembangan Masyarakat dari pembangunan Sampai Pemberdayaan. Yogyakarta: Aditya Media.

Somantri, Sutjihati. (2006). Psikologi Anak Luar Biasa. Bandung: RefikaAditama. Ambar, Teguh Sulistiyani. (2004). Kemitraan dan model-model Pemberdayaan. Yogjakarta: Gava Media.

Totok Mardikanto dan Purwoko Soebianto. ( 2012). Pemberdayaan Masyarakat dalam Perspektif Kebijakan Publik (Bandung : Alfabeta, 27.

Winarni, Tri. (1998). Memahami Pemberdayaan Masyarakat Desa Partisipatif dalam Orientasi Pembangunan Masyarakat Desa Menyongsong Abad 21: Menuju Pemberdayaan Pelayanan Masyarakat, Yogyakarta: Aditya Media.

Winarni, Tri. (1998). Orientasi Pembangunan Masyarakat Desa Menyongsong Abad 21 Menuju Pemberdayaan Pelayanan Masyarakat. Yogyakarta: Fisipol UGM.

Wawancara Eko Mulyadi, kepala desa Karang Patihan dan penggagas program pemberdayaan ekonomi. 21 Januari 2021.

Wawancara Keluarga tunagrahita Karang Patihan dan pendamping program 
JoIE: Journal of Islamic Economics | Hanafi Hadi Susanto

pemberdayaan ekonomi. 21 Januari 2021 